cambridge.org/cty

\section{Letter to the Editor}

Cite this article: Anderson RH (2021) Plus ca change, plus c'est la meme chose. Cardiology in the Young 31: 1715. doi: 10.1017/ S1047951121004121

Received: 11 September 2021 Accepted: 13 September 2021 First published online: 4 October 2021

\section{Keywords:}

Concordant ventriculo-arterial connections; anatomically corrected malposition; isolated ventricular inversion

\section{Author for correspondence:}

Professor R. H. Anderson, 60 Earlsfield Road, London, SW18 3DN, UK. Tel: 020-8870-4368. Email: sejjran@icl.ac.uk

\section{Robert H. Anderson}

Biosciences Division, Newcastle University, London, UK

Sir,

Plus ca change, plus c'est la meme chose. The epigram of Jean-Baptiste Alphonse Karr, written in 1849 issue in his journal "Les Guêpes", came to mind as I studied the interesting case reported by Mishra and colleagues from Chandigarh. ${ }^{1}$ The authors suggest that the term "isolated ventricular inversion" is controversial and cite a letter written by myself and my good friend James Wilkinson to emphasise their point. ${ }^{2}$ I admit that I had forgotten the content of the letter. On re-reading our letter, I discovered that we had criticised a manuscript published by the late lamented Manolo Quero-Jimenez, who became a close friend, and collaborated with us as we developed our system of sequential segmental analysis. ${ }^{3,4}$ Our "bone of contention" with Manolo had been the fact that, in the cases he had described together with Raposo-Sonnenfeld, the leaflets of the right-sided aortic valve had been described as being in fibrous continuity with the right-sided mitral valve. The point made by Wilkinson and myself was that, had the leaflets of the mitral valve been supported by a completely muscular infundibulum, then the case would have been described as "anatomically corrected malposition," rather than "isolated ventricular inversion". ${ }^{2}$ It is salutary then to read the response of Manolo. In the first instance, he wrote "With respect to the terminology, I understand Dr. Anderson's reasoning and I am not against what he is proposing". His concluding sentence, however, is more pertinent - "it is obvious, anyway, that for all of us our main interest should be not terminology but the most accurate description and plausible interpretation of the actual facts that are possible." I can but applaud, after a break of almost half a century, the wisdom of this statement. I would suggest, however, that we cannot provide "the most accurate description" without using the appropriate terminology. And, in the case beautifully illustrated by Mishra and colleagues, the ventricles are mirror-imaged relative to the normal arrangement, but they are not "inverted" in the sense of being upside down. More importantly, by my understanding, since the aortic valvar leaflets in their case are supported by a muscular infundibulum, the heart would be described by Dr Van Praagh as representing "anatomically corrected malposition $\{\mathrm{S}, \mathrm{L}, \mathrm{D}\}$ ", rather than "isolated ventricular inversion". It was to avoid such confusion that we subsequently suggested that rare cases of this type are better described as representing concordant ventriculo-arterial connections with parallel arterial trunks. ${ }^{5,6}$ Having read the account provided by Mishra and colleagues, I am the more convinced that it is the descriptive approach that provides the clarity rightly demanded by Dr Quero-Jimenez in his response to our initial letter.

Acknowledgements. None.

Financial support. This research received no specific grant from any funding agency, commercial or not-for-profit sectors.

Conflicts of interest. None.

Ethical standards. The authors assert that all procedures contributing to this work comply with the ethical standards of the relevant national guidelines on human experimentation and with the Helsinki Declaration of 1975, as revised in 2008.

\section{References}

1. Mishra AN, Naganur SH, Patel R, Bansal V, Rana P. Isolated ventricular inversion with hypoplastic right ventricle and pulmonary stenosis in an adolescent with situs solitus: a rare combination. Cardiol Young 2021; 15: $1-3$. DOI $10.1017 /$ S1047951121003607.

2. Anderson RH, Wilkinson JL. Isolated ventricular inversion with situs solitus. Br Heart J 1975; 37: 1202-1204.

3. Shinebourne EA, Macartney FJ, Anderson RH. Sequential chamber localization: logical approach to diagnosis in congenital heart disease. Br Heart J 1976; 38: 327-340.

4. Tynan MJ, Becker AE, Macartney FJ, Quero-Jimenez M, Shinebourne EA, Anderson RH. Nomenclature and classification of congenital heart disease. Br Heart J 1979; 41: 544-553.

5. Bernasconi A, Cavalle-Garrido T, Perrin DG, Anderson RH. What is anatomically corrected malposition? Cardiol Young 2007; 17: 26-34.

6. Cavalle-Garrido T, Bernasconi A, Perrin D, Anderson RH. Hearts with concordant ventriculoarterial connections but parallel arterial trunks. Heart 2007; 93: 100-106. 